\title{
Detection of human papillomavirus DNA by PCR in semen from patients with and without penile warts
}

\author{
J Green, E Monteiro, V N Bolton, P Sanders, P E Gibson
}

\begin{abstract}
Objectives-To determine the prevalence of urethral HPV infection, as indicated by the presence of HPV DNA in semen, in males with and without penile warts.
\end{abstract}

Design-Prevalence study of HPV types 6/11 and 16 DNA using PCR and Southern blot hybridisation analysis of semen.

Setting-Department of Genitourinary Medicine, Blundell Street Clinic, Leeds General Infirmary and the Assisted Conception Unit (ACU) Kings' College, London.

Subjects-Patients attending the Genitourinary Clinic for treatment of sexually transmitted diseases including penile warts and males attending Kings' ACU for investigations of infertility.

Main outcome measures-HPV DNA detected by polymerase chain reaction (PCR) and/or Southern blot hybridisation in semen.

Results-HPV DNA was detected by PCR in 23 of $27(85 \%)$ specimens from patients attending the GUM clinic for treatment of genital warts and in one of two specimens from patients attending the clinic for other conditions. By Southern blot, nine (33\%) of the 29 specimens from GUM clinic patients were HPV DNApositive. HPV DNA was detected by PCR in 43 of $104(41 \%)$ of specimens from males attending the ACU, whilst 70 of these tested by

Virus Reference Laboratory, Central Public Health Laboratories, 61 Colindale Avenue, London NW9 SHT, UK

J Green, P E Gibson

Blundell Street Clinic, Department of Genitourinary Medicine, Leeds General Infirmary, Leeds, LS1 3EX, UK

E Monteiro

King's Assisted Conception Unit, Department of Obstetrics and Gynaecology, King's College School of Medicine and Dentistry, Denmark Hill, London SE5 8RX, UK

V N Bolton

Department of Microbiology, University of Surrey, Guildford, Surrey, GU2 5XH, UK

P Sanders
Southern blot hybridisation were all negative for HPV DNA.

Conclusions-The data suggest that urethral HPV infections, as indicated by the presence of HPV DNA in semen, are prevalent in males with and without genital warts.

Introduction

Genital human papillomavirus (HPV) infections occur in both sexes and there is strong evidence to suggest that they can be sexually transmitted. ${ }^{12}$ While many studies have focussed on infections of females, far fewer have examined the prevalence of genital HPV infection in males, probably owing to the comparatively lower frequency of genital malignancy in males and to difficulties in obtaining adequate specimens. Grussendorf $e t a l^{\beta}$ demonstrated HPV DNA in $5.8 \%$ of penile swabs from the glans and sulcus corona glandis of men without clinical evidence of genital HPV infection. HPV DNA has also been demonstrated in semen, ${ }^{4}$ urine $^{5}$ and in prostatic cancer tissue ${ }^{67}$ suggesting that the urethra and/or prostate are potential reservoirs of HPV carriage.

The significance of semen as a vehicle in the transmission of genital HPV infections is unknown. We have reported previously the detection of HPV DNA by Southern blot hybridisation in human semen from males with intrameatal penile warts. ${ }^{8}$ In that study, HPV 6/11 DNA was detected in five of 15 semen specimens but HPV 16 was not detected. By the Southern blot procedure employed, HPV DNA levels in semen were very low and at the limit of detection (approximately $10^{6}$ copies $/ \mathrm{ml} \mathrm{semen).} \mathrm{We}$ now report the detection of HPV DNA in semen from males with and without genital warts by the more sensitive polymerase chain reaction (PCR). In addition to the 15 semen specimens originally described, ${ }^{8}$ we have tested a further 11 semen specimens from males attending a Genitourinary Medicine Clinic and 104 semen specimens from males attending an Assisted Conception Unit.

Material and methods

Study Populations: 14 semen specimens were received from males attending Department of Genitourinary Medicine, Leeds Infirmary. Patients 
were grouped as follows: Group A were males attending for the treatment of intrameatal warts (five specimens received); Group B were patients attending for treatment of genital warts (seven specimens received); Group $C$ were patients with no evidence of penile warts (two specimens received).

One hundred and four semen specimens were obtained from patients attending King's College Assisted Conception Unit for investigations of infertility.

DNA extraction for Southern blot hybridisation: Semen was digested with proteinase $\mathrm{k}(100 \mu \mathrm{g} / \mathrm{ml})$ and $1 \%$ SDS and the nucleic acid extracted twice with an equal volume of $\mathrm{phenol} / \mathrm{chloroform}$ and once with chloroform/iso-amyl alcohol (IAA). Following digestion with RNAse A $(50 \mu \mathrm{g} / \mathrm{ml})$ one phenol/ chloroform extraction and one chloroform/iso-amyl extraction and one chloroform/iso-amyl alcohol extraction were performed and the DNA precipitated with ethanol, pelleted, washed with $70 \%$ ethanol, dried and resuspended in $50 \mu \mathrm{l}$ TE buffer. The undigested extracted DNA was electrophoresed and transferred to nylon (Amersham Hybond N) by the method of Southern. ${ }^{9}$

Probe labelling and hybridisation: HPV 6, 11, 16 clones were kindly provided by $\mathrm{Dr} \mathrm{H}$ zur Hausen (Deutsches Krebsforschungszentrum, Heidelberg). HPV DNA inserts were excised from vector sequences and recloned into pGemini vectors using manufacturers' recommended procedures (Promega Biotec). Recombinant clones were amplified and HPV DNA excised from vector sequences by restriction enzyme digestion followed by agarose gel electrophoresis and elution.

The viral DNAs were radiolabelled with ${ }^{32} \mathrm{P}$ dCTP by random primer extension (Pharmacia LKB Biotechnology Oligo labelling kit: $27-9250-01)$ to specific activities of approximately $5 \times 10^{8} \mathrm{dpm} / \mu \mathrm{g}$. Nylon membranes were prehybridised in $6 \times$ SSC, $5 \times$ Denhardt's solution, $0.5 \%$ SDS and $200 \mu \mathrm{g} / \mathrm{ml}$ salmon sperm DNA at $65^{\circ} \mathrm{C}$ for 2 hours. Radiolabelled HPV probe was added to give approximately $10^{6} \mathrm{cpm} / \mathrm{ml}$ hybridisation solution. Hybridisation occurred at $68^{\circ} \mathrm{C}$ overnight. The membrane was then washed sequentially in $2 \times \operatorname{SSC} / 0 \cdot 1 \%$ SDS, $1 \times \mathrm{SSC} / 0 \cdot 1 \%$ SDS and $0.1 \times \mathrm{SSC} / 0 \cdot 1 \% \mathrm{SDS}$, at $65^{\circ} \mathrm{C}$. The membrane was exposed to X-ray film (Amersham MP hyperfilm) at $-70^{\circ} \mathrm{C}$ overnight. Membranes were re-exposed for 7 days if necessary. After hybridisation with a pooled HPV 6/11 probe, the membrane was stripped of probe by washing with $0.4 \mathrm{M} \mathrm{NaOH}$ for 30 minutes at $45^{\circ} \mathrm{C}$ and reprobed with HPV 16.

Restriction enzyme digestion: Semen specimens positive by Southern hybridisation were further examined by restriction enzymic digestion. An $800 \mu \mathrm{l}$ aliquot of each HPV-positive semen specimen was spun in a microcentrifuge for 30 seconds. The DNA was extracted from the pellet and supernatant fractions separately using the procedures described previously. The extracted DNA was then digested simultaneously with BamH1 and EcoR1 restriction enzymes in order to determine the HPV DNA type present. ${ }^{14}$ The digests were then electrophoresed on a $0.9 \%$ agarose gel and Southern blotted overnight onto nylon membranes. The membranes were hybridised with specific HPV DNA probes as described above.

DNA extraction for PCR: $400 \mu \mathrm{l}$ of semen were combined with an equal volume of extraction buffer (8 M urea, $0.4 \mathrm{M} \mathrm{NaCl}, 0.2 \mathrm{M}$ Tris $\mathrm{pH} 8.0,1 \% \mathrm{n}$ lauroylsarcosine, $0.02 \mathrm{M}$ diamino cyclohexane tetraacetic acid (CDTA)). Proteinase $\mathrm{k}$ was added to $100 \mu \mathrm{g} / \mathrm{ml}$ and digestion allowed to occur at $55^{\circ} \mathrm{C}$ for 1 hour. Nucleic acid was extracted twice with phenol/ chloroform and once with chloroform/IAA and then precipitated with $0.5 \mathrm{M} \mathrm{NaCl}$ and two volumes ethanol at $-20^{\circ} \mathrm{C}$ overnight (or two hours at $-70^{\circ} \mathrm{C}$ ). The DNA was pelleted by centrifugation, washed with $70 \%$ ethanol, dried under vacuum and resuspended in $100 \mu$ l sterile $\mathrm{H}_{2} \mathrm{O}$.

Precautions to prevent the generation of false positive results: Three separate rooms, free from cloned or amplified DNA were used for reagent preparation, specimen DNA extraction and amplification. Recommended procedures ${ }^{10}$ including use of dedicated positive displacement pipettes, gloves, dedicated microfuges and other equipment, sterile tubes and racks were adopted. Controls were included with each batch of DNA extractions (three HPV-negative cell cultures) and amplifications (two distilled water controls and a $100 \mathrm{fg}$ cloned DNA positive control).

Polymerase Chain Reaction: Oligonucleotide primers used for the detection of HPV 11 and HPV 16 DNA were those described by Young et al. ${ }^{11}$ These were synthesised at a concentration of $0 \cdot 2 \mu \mathrm{M}$ on a model 380 Applied Biosystems DNA synthesiser.

Extracted semen DNA (8 $\mu$ l approximately $500 \mathrm{ng}$ nucleic acid) was added to a PCR reaction mix containing $67 \mathrm{mM}$ Tris (pH 8.8, 25 $\left.{ }^{\circ} \mathrm{C}\right), 16.6 \mathrm{mM}$ $\left(\mathrm{NH}_{4}\right)_{2} \mathrm{SO}_{4}, 6.7 \mathrm{mM} \mathrm{MgCl}, 10 \mathrm{mM}$ B-mercaptoethanol, $6.7 \mu \mathrm{M}$ EDTA, $0.17 \mathrm{mg} / \mathrm{ml}$ bovine serum albumin, $1.5 \mathrm{mM}$ each of dCTP, dGTP, dATP and TTP (Pharmacia) and 25 picomoles of each primer. An overlay of $75 \mu \mathrm{l}$ mineral oil was added to prevent evaporation during amplification procedure.

PCR reactions were performed in $50 \mu \mathrm{l}$ volumes using a Cambion MKII Intelligent Heating Block. After an initial denaturation step of $95^{\circ} \mathrm{C}$ for 5 minutes and annealing at $50^{\circ} \mathrm{C}$ for 30 seconds, 1.5 units Taq polymerase were added to each reaction tube. This was followed by 35 cycles of $67^{\circ} \mathrm{C}$ for 3 minutes, $91^{\circ} \mathrm{C}$ for 1 minute and $50^{\circ} \mathrm{C}$ for 1 minute followed by a final extension at $67^{\circ} \mathrm{C}$ for 5 minutes. 
Post-amplification analysis: Following PCR, oligomer hybridisation as described by Kellogg and Kwok ${ }^{12}$ was performed.

Preparation of probe oligonucleotide: DNA oligomers of 30 bases in length, complementary to an internal sequence of the amplified product, were synthesised as described. Fifty picomoles of oligomer probe were $3^{\prime}$ end-labelled with ${ }^{32} \mathrm{P}$-ddATP by the enzyme terminal deoxytransferase (TdT). Procedure and reagents were obtained in kit form from DuPont (Kit code NEP 100). Labelled oligomer was separated from unincorporated nucleotide on a Sephadex G50 column ("Nick" column, Pharmacia LK Biotechnology). The probe was obtained in a volume of $0.4 \mathrm{ml}$ and usually had an activity of $3 \times 10^{4} \mathrm{cpm} / \mu \mathrm{l}$.

Oligomer hybridisation: To a $15 \mu \mathrm{l}$ aliquot of each reaction mix was added $10 \mu \mathrm{l}$ probe mix consisting of $4 \mu \mathrm{l} 60 \mathrm{mM} \mathrm{NaCl}, 1 \mu \mathrm{l} 40 \mathrm{mM}$ EDTA (pH 8.0), 0.15 pmol ${ }^{32} \mathrm{P}$-end-labelled probe $\left(\sim 10^{4}\right.$ counts $)$ and sterile $\mathrm{H}_{2} \mathrm{O}$ to a final volume of $10 \mu \mathrm{l}$.

After thorough mixing, the tubes were heated to $95^{\circ} \mathrm{C}$ for 5 minutes in order to denature the double stranded amplification product, and then cooled to $55^{\circ} \mathrm{C}$ for 15 minutes. After brief centrifugation in order to bring down tube contents, the mixes were electrophoresed on a $4 \%$ composite $(3 \%$ Nuseive, $1 \%$ Seakem, FMC Biochemicals, USA) agarose gel, stained with ethidium bromide and photographed. The gel was then sealed in a clear polythene bag and exposed directly to Amersham Hyperfilm MP x-ray film overnight at $-70^{\circ} \mathrm{C}$.

\section{Results}

Southern blot hybridisations were performed on 70 semen specimens from patients attending an ACU and on 14 specimens from patients attending a GUM clinic. The table shows the combined Southern blot data of this and the earlier study. ${ }^{8}$ Eight of $20(40 \%)$ specimens from males with intrameatal warts (Group A) and one of seven (14\%) specimens from males with penile warts (Group B) were positive for
HPV 6/11 DNA. Two specimens from males without penile or intrameatal warts (Group C) were negative as were 70 specimens from the ACU.

When tested by PCR, HPV positivity rates for population groups A and B were $100 \%$ and $56 \%$ respectively. All specimens from males with intrameatal warts were positive for HPV 16 and 19 of $20(95 \%)$ were also positive for HPV 11 . Four of seven specimens from males with penile warts contained HPV 11 DNA and three of these were also positive for HPV 16 DNA. One of two specimens from males without penile warts was positive for HPV 16 DNA.

Of 104 semen specimens from patients attending the ACU, $23(22 \%)$ were positive for HPV 11 and 35 (33\%) were positive for HPV 16. Fifteen specimens contained both HPV types 11 and 16.

\section{Discussion}

PCR has been applied to the detection of HPV DNA in semen in order to estimate the prevalence of urethral HPV infections in populations with low and high incidence of penile warts, to determine semiquantitatively the extent of virus excretion into semen by comparing HPV detection by PCR and Southern blot and to assess the significance of semen in the transmission of genital HPV infections.

In order to determine the extent of HPV shedding into semen, we have tested specimens from males attending a Genitourinary Medicine (GUM) clinic for treatment of intrameatal penile warts. By Southern blot analysis, $40 \%$ and $0 \%$ were positive for types $6 / 11$ and 16 respectively. By PCR, all were positive for HPV 16 DNA and 19 of $20(95 \%)$ positive for HPV 6/11. It is interesting to note that HPV 16 could be detected in all specimens by PCR but in none by Southern blot. We know the limits of detection of Southern blot and PCR to be approximately $10^{4}$ and 10-50 HPV DNA copies respectively (data not shown). Although HPV 16 is shed into semen, clearly the number of viral genome copies is lower than that of HPV 6/11. Types 6 and 11 are

Table HPV DNA in semen as determined by Southern blot hybridisation and PCR

\begin{tabular}{|c|c|c|c|c|c|c|}
\hline \multirow[b]{2}{*}{ GU Med Clinic population } & \multicolumn{3}{|c|}{ Southern blot } & \multicolumn{3}{|l|}{ PCR } \\
\hline & $H P V 6 / 11$ & HPV 16 & $H P V+$ & $H P V 11$ & $H P V 16$ & $H P V+$ \\
\hline $\begin{array}{l}\text { Group } A \\
\quad \text { Intrameatal warts }\left(\mathrm{n}=20^{\star}\right)\end{array}$ & $8(40 \%)$ & 0 & $8(40 \%)$ & $19(95 \%)$ & $20(100 \%)$ & $20 \ddagger(100 \%)$ \\
\hline $\begin{array}{l}\text { Group } B \\
\quad \text { Penile warts }(n=7)\end{array}$ & $1(14 \%)$ & 0 & $1(14 \%)$ & $4(56 \%)$ & $3(43 \%)$ & $4 \S(56 \%)$ \\
\hline $\begin{array}{l}\text { Group } C \\
\quad \text { No warts }(\mathrm{n}=2)\end{array}$ & 0 & 0 & 0 & 0 & $1(50 \%)$ & $1(50 \%)$ \\
\hline Infertility clinic population $(n=104 \dagger)$ & 0 & 0 & 0 & $23(22 \%)$ & $35(33 \%)$ & $43 \|(41 \%)$ \\
\hline
\end{tabular}

*includes 14 specimens tested in previous study (reference 8 ).

$\dagger 104$ specimens tested by PCR of which only 70 were tested by Southern blot.

tincludes 19 dual HPV $11+16$ infections.

§includes 3 dual HPV $11+16$ infections.

|includes 15 dual HPV $11+16$ infections. 
most commonly found associated with condylomatous lesions whereas type 16 frequently exists in flat pigmented lesions or in clinically inapparent lesions. ${ }^{13}$ It seems likely that cell shedding will occur more readily from condylomatous lesions than from HPV 16-related lesions and this may explain our findings. Alternatively, the viral copy number per infected cell may vary between HPV types. We also tested semen from patients attending the GUM clinic for treatment of non-intrameatal penile warts and found $56 \%$ positive for HPV 11 and/or HPV 16 DNA suggesting that urethral infections are present in approximately half of this patient group.

The prevalence of genital HPV infections in males in the general population is difficult to determine due to a lack of satisfactory sampling techniques. Penile scrapes yield only limited amounts of material though they can be useful in sampling outer surfaces of the penis and areas of the urethra proximal to the urinary meatus. Urine has been used to test for urethral carriage of HPV but semen is perhaps more useful in investigations of the processes of sexual transmission. However, semen specimens are difficult to obtain from the general population and it was because of this that we tested semen from males attending King's ACU as representative of a population with a low incidence (less than $1 \%$; Dr Ruth Curson, personal communication) of penile warts. HPV DNA was detected by PCR in $41 \%$ of specimens tested, $8 \%$ containing HPV 11 DNA only, $19 \%$ HPV 16 DNA only and $14 \%$ containing both HPV 11 and 16 DNA. When tested by Southern blot, however, no HPV DNA was detected. Following PCR, ethidium bromide staining of electrophoresesed amplified products revealed only faintly visible DNA bands and oligomer hybridisation was required for clear visualisation of positive specimens, demonstrating that only very small quantities (1-10 fg DNA equivalent to approximately 100 genome copies) of HPV DNA were present. As no in vitro culture system for HPV is currently available, it is not possible to determine whether the DNA detected represents infectious virus.

These data suggest that urethral carriage of human papillomaviruses, as indicated by the presence of HPV DNA in semen, is prevalent among populations in which the incidence of clinically apparent genital warts is low. Determination of infectivity of HPV DNA in semen awaits the development of a suitable in vitro culture system.

The authors thank Dr Philip Mortimer and Dr Nicholas Hallam for their critical reading of the manuscript and Dr Jeremy Dale for helpful advice.

Address correspondence to Dr J Green.

1 Wickendon C, Hanna N, Taylor-Robinson D, et al. Sexual transmission of human papillomaviruses in heterosexual and male homosexual couples, studied by DNA hybridisation. Genitourinary Med 1988;64:34-8.

2 Schneider A, Kitchmayr R, de Villiers EM, Gissman L. Subclinical human papillomavirus infections in male sexual partners of female carriers. $J$ Urol 1988;140:1431-4.

3 Grusendorf-Conen E-I, Meinhof W, de Villiers E-M, Gissman L. Occurrence of HPV genomes in penile smears of healthy men. Arch Dermatol Res 1987;279:S73-S75.

4 Ostrow RS, Zachow KR, Nimura M, et al. Detection of papillomavirus DNA in semen. Science 1986;231:731-3.

5 Melchers WJG, Schift R, Stolz E, Lindeman J, Quint WGV. Human papillomavirus detection in urine samples from male patients by the polymerase chain reaction. J Clin Microbiol 1989;27:1711-4.

6 McNicol PJ, Dodd JG. Detection of human papillomavirus DNA in prostate gland tissue by using the polymerase chain reaction amplification assay. J Clin Microbiol 1990;28:409-12.

7 McNicol PJ, Dodd JG. Detection of papillomavirus DNA in human prostatic tissue by Southern blot analysis. Can Microbiol 1990;36:359-62.

8 Green J, Monteiro E, Gibson P. Detection of human papillomavirus DNA in semen from patients with intrameatal penile warts. Genitourin Med 1989;65:357-60.

9 Southern E. Detection of specific sequences among DNA fragments separated by gel electrophoresis. J Mol Biol 1975;98:503-17.

10 Kwok S, Higuchi R. Avoiding false positives with PCR. Nature 1989;339:237-8.

11 Young LS, Bevan IS, Johnson MA, et al. The polymerase chain reaction: a new epidemiological tool for investigating cervical human papillomavirus infection. $B M J$ 1989;298:14-18.

12 Kellog DE, Kwok S. Detection of human deficiency virus. In: Innis MA, Gelfand DH, White TJ, Sninsky JJ, et al. PCT Protocols: a Guide to Methods and Applications. Chaper 40. 1990. Academic Press.

13 Selvey L, Buntine DW, Kennedy L, Frazer IH. Male partners of women with genital human papillomavirus infection: An assessment of colposcopic abnormalities by histological examination and human papillomavirus hybridisation. Med $J$ Aust 1989;150:479-81.

14 Gissman L, Volker D, Schultz-Coulon H-J, zur Hausen H. Molecular cloning and characterisation of human papillomavirus DNA derived from a laryngeal papilloma. $J$ Virol 1982;44:1:393-400.

Accepted for publication 7 March 1991 